YOGINDER SIKAND

\section{The Deendar Anjuman Between Dialogue and Conflict}

The present controversy concerning the Anjuman's alleged role in the bomb blasts must be viewed in the context of the sect's origins. Siddiq Hussain, founder of the Anjuman, was born in 1886 at Balampet in the Gulbarga district, then part of the Nizam's Dominions. As a young man, he joined the Qadiani community, but soon renounced his membership, accusing the Qadianis of being kafirs for considering Mirza Ghulam Ahmad as a prophet. It is likely that he, at this time, moved closer to the rival Laho branch of the Ahmadis, who split off from the main Ahmadi jamacat over the question of the status of the Mirza. Unlike the Qadianis, the Lahoris, led by the well-known Is lamic scholar Maulana Muhammad cAli, in sisted that the Mirza was not a prophet but simply a mujaddid (renewer of the faith). It is possible that Siddiq Hussain might actually have formally joined the Lahori jamacat, for in his tract, 'Acada-i-Islam' ('Enemies of Islam'), dating back to the mid-1920s, he wrote that he and members of his Anjuman believed that Mirza Ghulam Ahmad had been sent by God as the mujaddid of the 14t Islamic century. He also indicated that he continued to hold the Mirza in great esteem.

\section{Launching of the Mission}

In early 1923, the Arya Samaj, a militan Hindu chauvinist group, launched a massive drive to bring into the Hindu fold hundreds of thousands of Muslims. Muslim leaders responded by launching efforts at countering the Aryas through various Islamic missionary (tabligh) groups. Alarmed by the growing success of the Aryas, Siddiq Hussain set about launching his own missionary campaign among the Hindus, seeking to bring them into the Muslim fold. He first turned his attention to the Lingayats, a group of Shiva-worshippers living mainly in the Kannada-speaking districts of the Nizam's Dominions. Once, while on a trip to the shrine of Kodekkal Basappa, known to his Muslim followers as Muhammad Sarwar, a Sufi highly venerated by the local Lingayats, he reportedly heard that the Sufi had predicted the arrival of a saviour of the Lingayats, in the form of 'Deendar Channabasaveswara', who would be born in a Muslim family and would 'make the Hindus and Muslims one'. This, he announced, was a prophecy heralding his own arrival, claiming that in a dream God informed him that he had been appointed as an avatar of the Lingayat sain Channabasaveswara to bring all the Hindus of India to Islam. He now also claimed to be the saviour of the Hindus, the Kalki Avatar, who would herald the arrival of the age of truth (sat yug) in 1943, with only those who accepted Islam being saved. The Deendar Channabasaveswara, along with his army of Pathan followers would, as he claimed that the Hindu scriptures foretell, 'empty the treasuries of the [temples of] Tirupati and Hampi', and ensure that 'there is not one idol left standing in any temple' in the country. He would then set about 'uniting all the 101 castes [zat]', by making all Hindus Muslim. In the process, the power of the Brahmins would be completely destroyed. Final- ly, the Deendar Channabsaveswara would be recognized as the 'king of kings' (badshahon ke badshah).

It is possible that, not finding a warm response to his appeals among the Lingayats, Siddiq Hussain turned his attention to other Hindu groups as well. As in his missionary work among the Lingayats, Islam was presented here not as the negation, but rather as the fulfilment of Hinduism. In a booklet intended for a Hindu readership, Siddiq Hussain wrote that God had sent prophets to all peoples, and that they all taught the same religion (din), al-Islam, and that the last of these was the Prophet Muhammad. All the previous scriptures, he claimed, had predicted the arrival of Muhammad as God's last prophet for all mankind. Therefore, it was the duty of all non-Muslims to accept Muhammad and his teachings in accordance with what their own prophets had predicted about him. He argued that the coming of Muhammad as the universal saviour had been predicted in many Hindu scriptures. Quoting liberally from them, he remarked that the arrival of Muhammad as 'the World Teacher' had been 'prophesied so vividly and in such detail' in the books of the Hindus as 'cannot be found in any other religious texts'. Hence, Hindus had to convert to Islam if they were to be saved and if they were to remain true to the commandments of their own scriptures.

The Muslims, whom Siddiq Hussain had looked to for support in his mission, seem either to have ignored him or to have come forth in open opposition. Numerous culama issued fatawa of kufr (infidelity) against him on account of his claims to being an avata of Channabasaveswara, declaring him to be a crypto-Qadiani, an allegation that he strove hard to refute. An enraged Muslim even went so far as to attempt to kill him. Despite this, Siddiq Hussain persisted in trying to convince Muslims of the legitimacy of his claims and of the importance of his mission, presenting his work as being in line with orthodox Islam. Siddiq Hussain stressed that he had been sent on a divine mission, declaring that the Prophet Muhammad himself had appointed him as the imam ul-nas (imam of the people) and the imam-iaqwam-i-calam (imam of all peoples of the world) and, in that capacity, as the 'brother (bhai) of all Muslims'. Despite his efforts, Sidillusioned with the lukewarm support he received from the Muslims of Hyderabad, which may have been the main reason for his subsequent decision in 1932 to leave the state and head northwards to Yaghestan, in the Pathan borderlands.

\section{Hijra and Jihad}

Anjuman sources describe Siddiq Hussain's migration, along with several of his close followers, to Yaghestan as an emulation of the Prophet's Hijra from Mecca to Medina in order to stir up the Pathans. Then, at the head of a grand Pathan army, he would descend to the Indian plains, prediq Hussain seems to have been greatly dis- sumably to fight the British and establish Isamic rule in the country, with himself as the imam. According to an Anjuman source some $6,000,000$ Pathans are said to have joined his mission of jihad. In 1934, he announced that he had received a divine revelation (ilham) that all of India would shortly convert to Islam. 'Rejoice! Oh Musalmans!' he declared to the obvious delight of his fo lowers, 'the whole of India will soon turn Muslim'. Presumably, the time was now rip for the jihad. His rousing up of the Pathan for war was now taken seriously by British authorities, who arranged for his arrest in 1936 and sent him back to Hyderabad, where he spent the next few years in jail.

In 1939, following his release, he set up a military training centre for his followers in Hyderabad, the Tehrik Jamicat-i-Hizbullah (The Movement of the Party of God). At this time, he also penned two tracts: 'The Practical Science of War' and 'The Principal Armie of Asia and Europe'. Alongside these preparations for war, he kept up his missionary work, dispatching letters to several Indian and British leaders, including Gandhi, the Viceroy and King George V, asking them to convert to Islam.

\section{7 and after}

By the end of 1946, fierce rioting between Hindus and Muslims had spread all across India, and Hyderabad was not left unaffected. Large-scale massacres of Muslims in the western districts of the Nizam's Dominions were reported. Reacting to this, Siddiq Hussain appealed to his followers to commence 'defensive fighting' against 'the enemies of Islam'. In late 1948, Indian troops invaded and took over Hyderabad. According to Anjuman sources, Siddiq Hussain and his folowers fought the Indian forces on 27 different fronts, but were soon captured at their headquarters at Asif Nagar and taken into custody. Siddiq Hussain was later released remaining alive for barely two months, a period in which he prepared an ambitious programme for missionary work in India. In response to the changed political context, he prepared a new method of missionary work for his followers to adopt. This he gave the name of the Panch Shanti Marg (The Five Pillars of the Way of Peace). This Sanskrit name was, it seems, deliberately chosen to commend the Anjuman to the Hindus, although it appears to have been modelled on the 'five pillars' of Sunni Islam, including eko jagadishwar (tauhid, belief in the One God) eko jagat guru (belief in Muhammad, the 'seal of the prophets' (khatm al-nabiyyin), as the 'World Teacher'); sarva avatar satya (belief in all the prophets as true); sarva dharma granth satya (belief in all religious scriptures as true); and sammelan prarthana ('collective prayer', the Islamic form of worship). In this manner, the missionary agenda of the Anjuman was played down and an impression was created that the Anjuman was genuinely committed to a generous ecumenism transcending all religious barriers.
Siddiq Hussain died in April 1952, and was succeeded by Sayyed Amir Hussain as the head of the community. Under Amir Hussain, the Anjuman continued the missionary activities begun by its founder, projecting itself as a peaceful group, committed to inter-communal harmony, which organizes regular inter-religious dialogue conferences. It was estimated that by the late 1990s, the Anjuman counted some 15,000 members, mainly in Hyderabad and in several towns and villages in South India, including some 100 full-time roving missionaries.

Thus, militancy and pacifism seem to have characterized the missionary strategy of the Anjuman at different times depending on the broader socio-political context. If there is any truth at all to the allegations that the Anjuman was involved in the recent bomb blasts, it would point to a return to Siddiq Hussain's jihadist strategy of the 1930s as a response to the growing challenge of Hindu militancy in India today.
Yoginder Sikand is a post-doctoral research scholar associated with the Department of History, Royal Holloway, Egham, Surrey, UK. E-mail:ysikand@hotmail.com 